\title{
Carbenicillin Phenyl
}

National Cancer Institute

\section{Source}

National Cancer Institute. Carbenicillin Phenyl. NCI Thesaurus. Code C79761.

The phenyl ester of carbenicillin, a broad-spectrum, semisynthetic penicillin derivative with antibacterial activity. Following absorption, carbenicillin phenyl sodium is rapidly hydrolyzed to the active carbenicillin, which binds to and inactivates penicillin-binding proteins (PBPs) located on the inner membrane of the bacterial cell wall, thereby preventing the cross-linkage of peptidoglycans, which are critical components of the bacterial cell wall. This leads to a weakening of the bacterial cell wall, eventually causing bacterial cell lysis. 